\title{
Relaciones entre la carbonatación del cemento portland, el grado de cocción del clínker y algunos fenómenos expansivos en el ensayo de autoclave
}

A. RUIZ DE CAUIIA, Di. en Crencias

A petición de nuestros lectores y debido a las dificultades encontradas para leer los números de las figuras correspondientes al trabajo:

«Relaciones entre la carbonatación del cemento portland, el grado de cocción del clínker y algunos fenómenos expansivos en el ensayo de autoclave»

de A. Ruiz de Gauna, que apareció en el número 160 (Oct.-Nov.-Dic. 1975) de nuestra Revista, publicamos en el presente número, para facilitar la comprensión del trabajo, las mencionadas figuras a un tamaño ampliado.

\section{Erratas advertidas sobre este artículo en el $n .^{\circ} 160$ de Materiales de Construcción}

En la pág. 71, llamada (*), dice:

«... según cita el segundo asterisco pero en presencia de $\mathrm{CO}_{2}$ ».

debe decir:

«... según cita la nota de pie de página de la pág. 58 pero en presencia de $\mathrm{CO}_{2}$ »

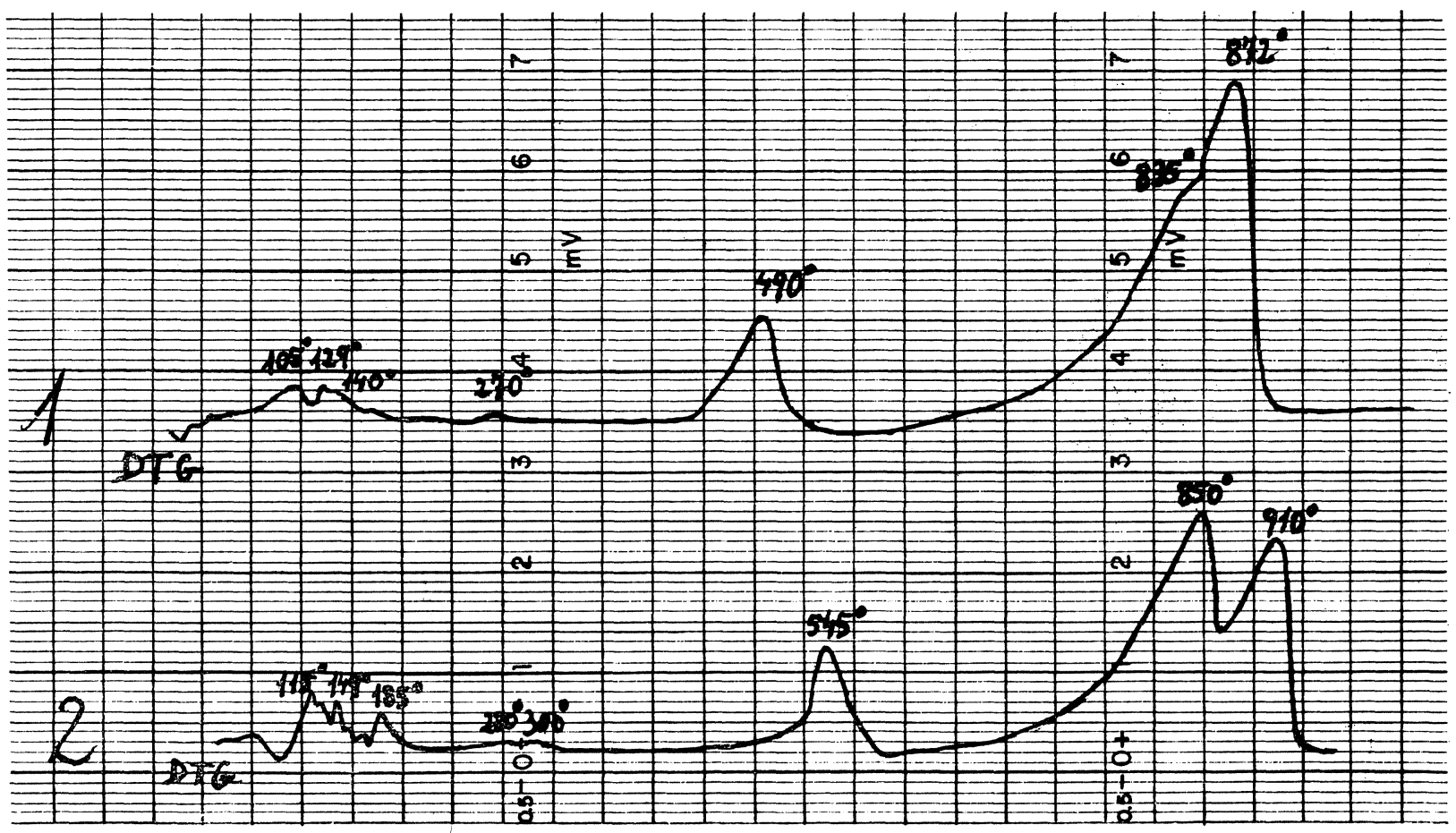

Fig. 1.-Comparación de las curvas DTC, realizadas en atmósfera de ar gón (1) y de vapor de agua (2), de un cemento portland anhidro. 


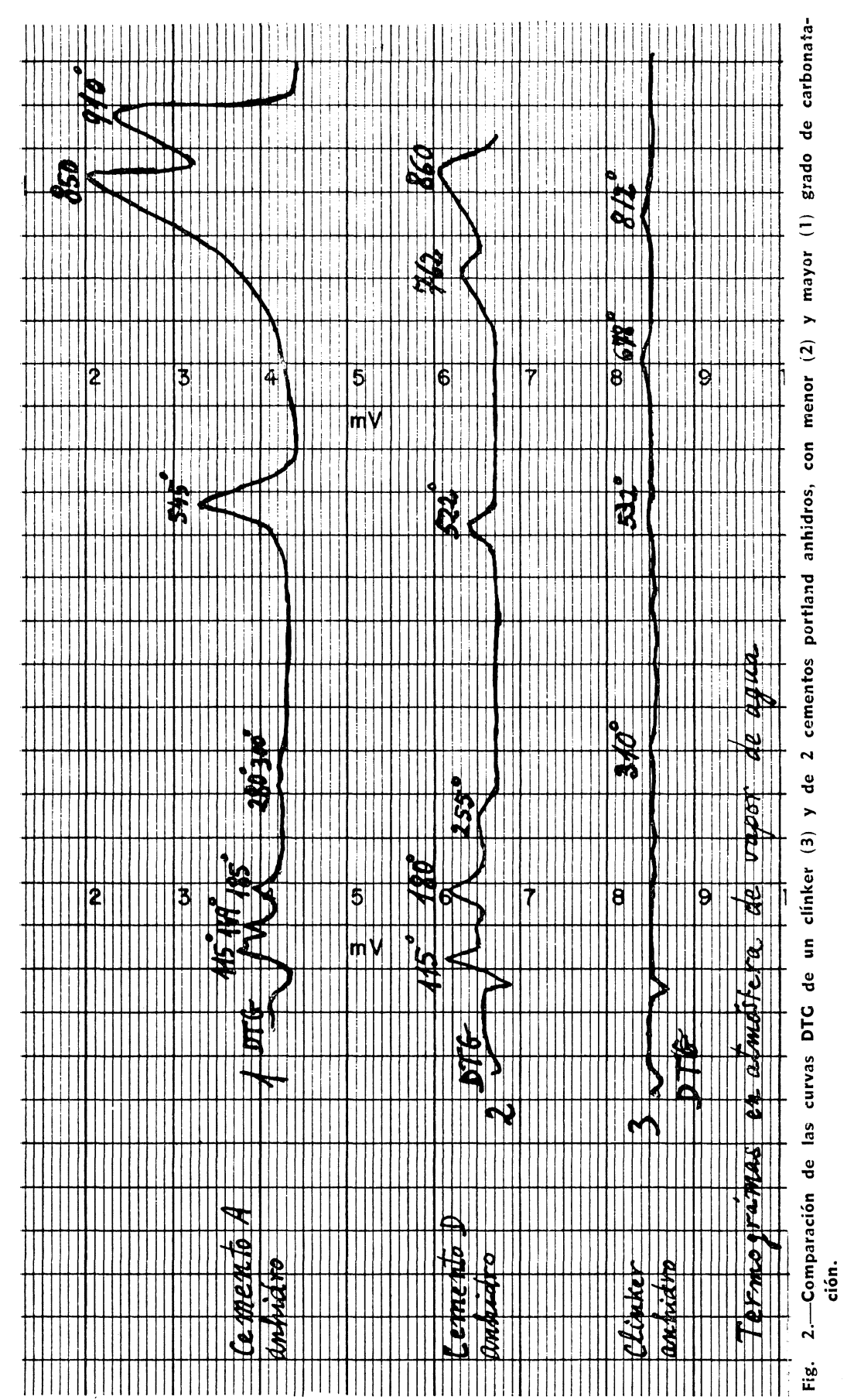

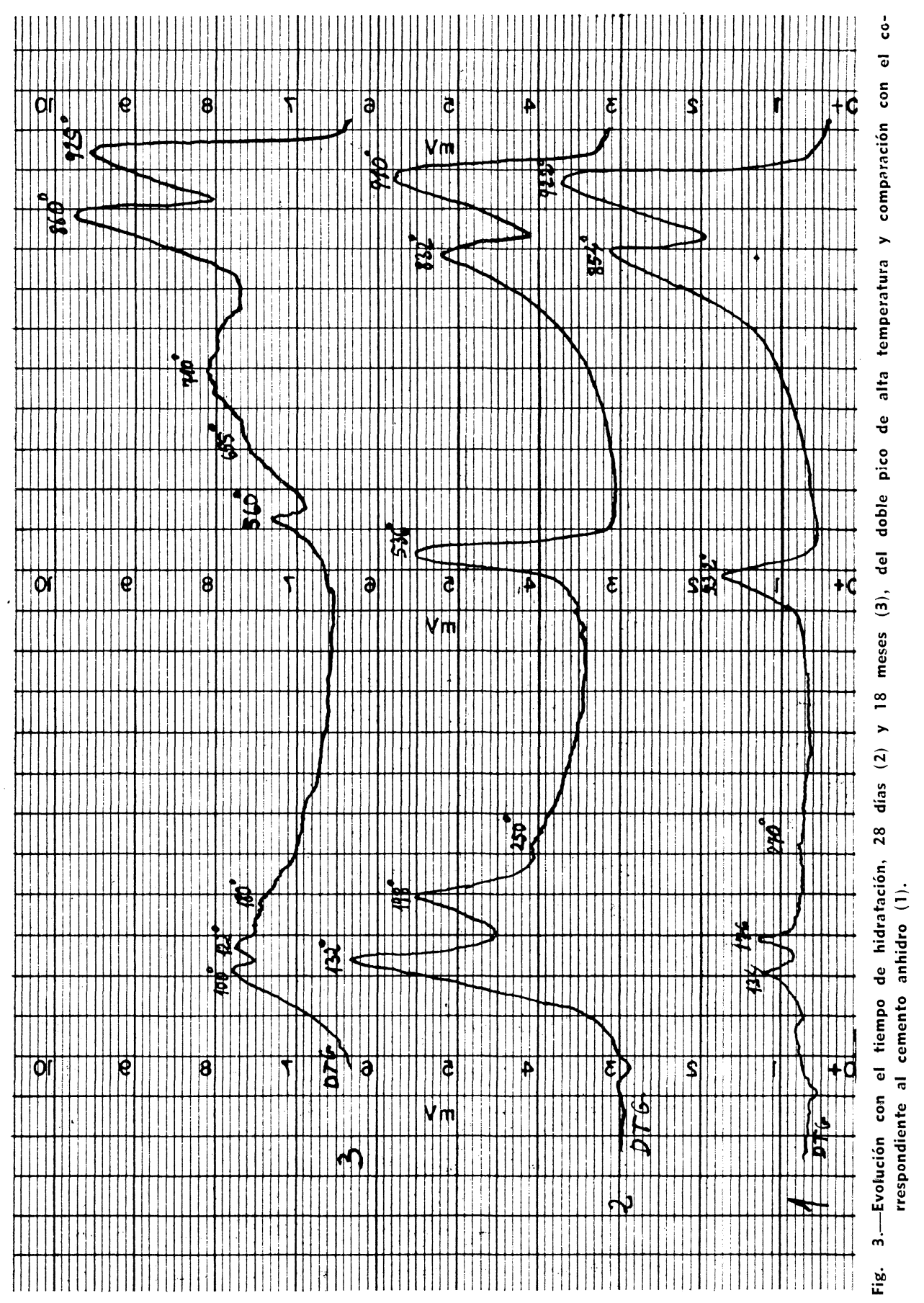




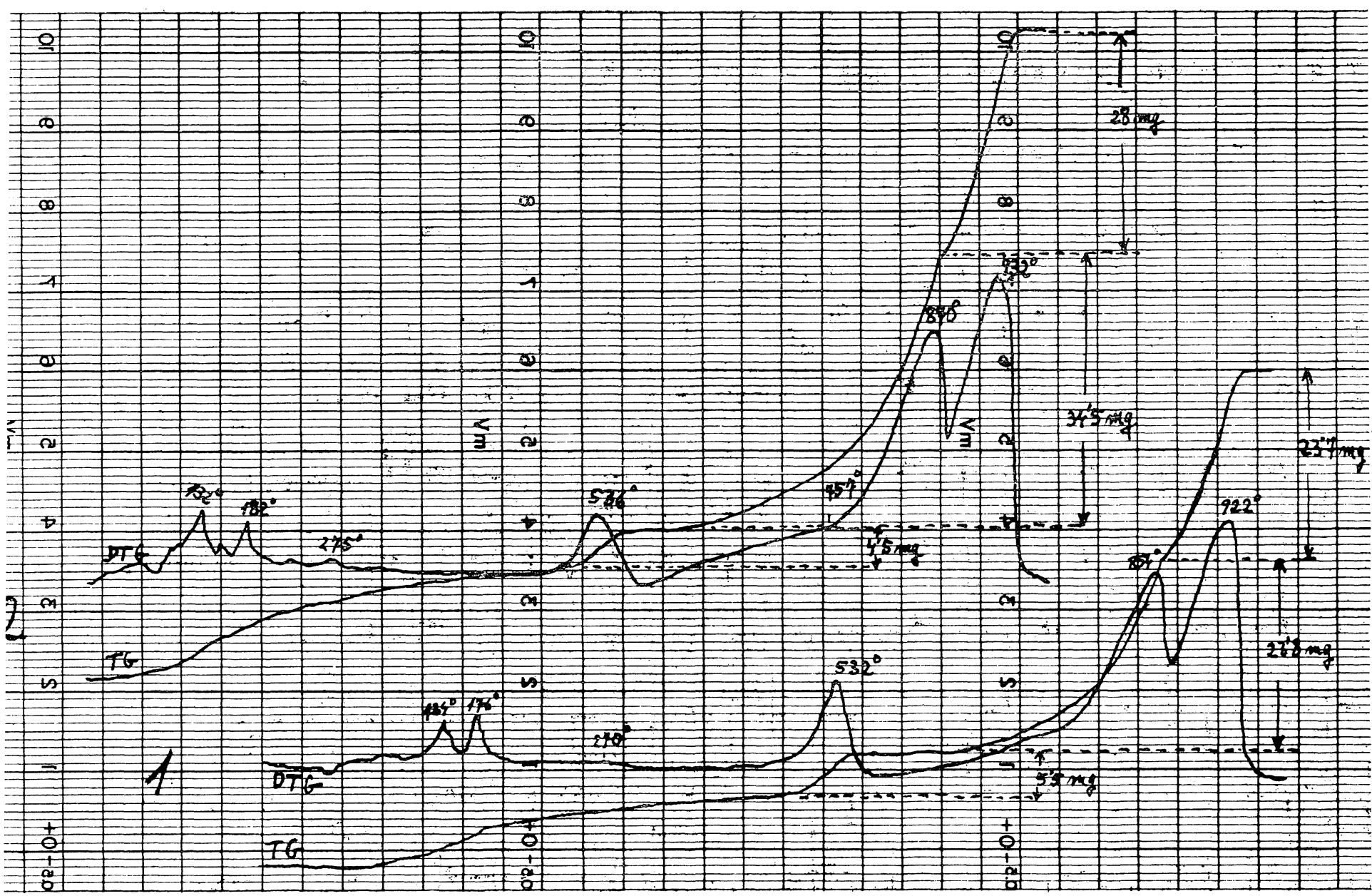

Fig. .4-Evọlución del doble pico de alta temperatura en la carbonatación forzada.

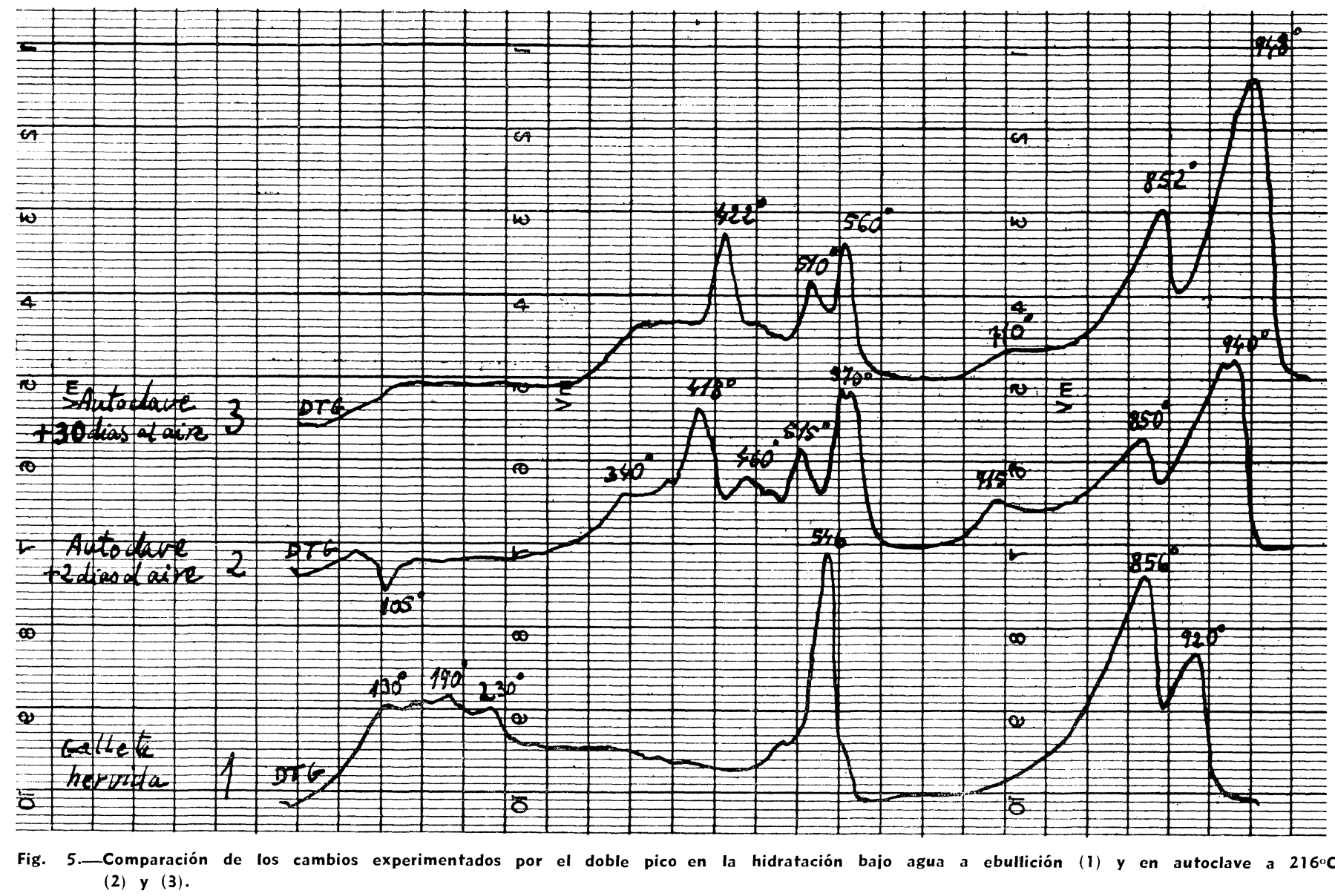




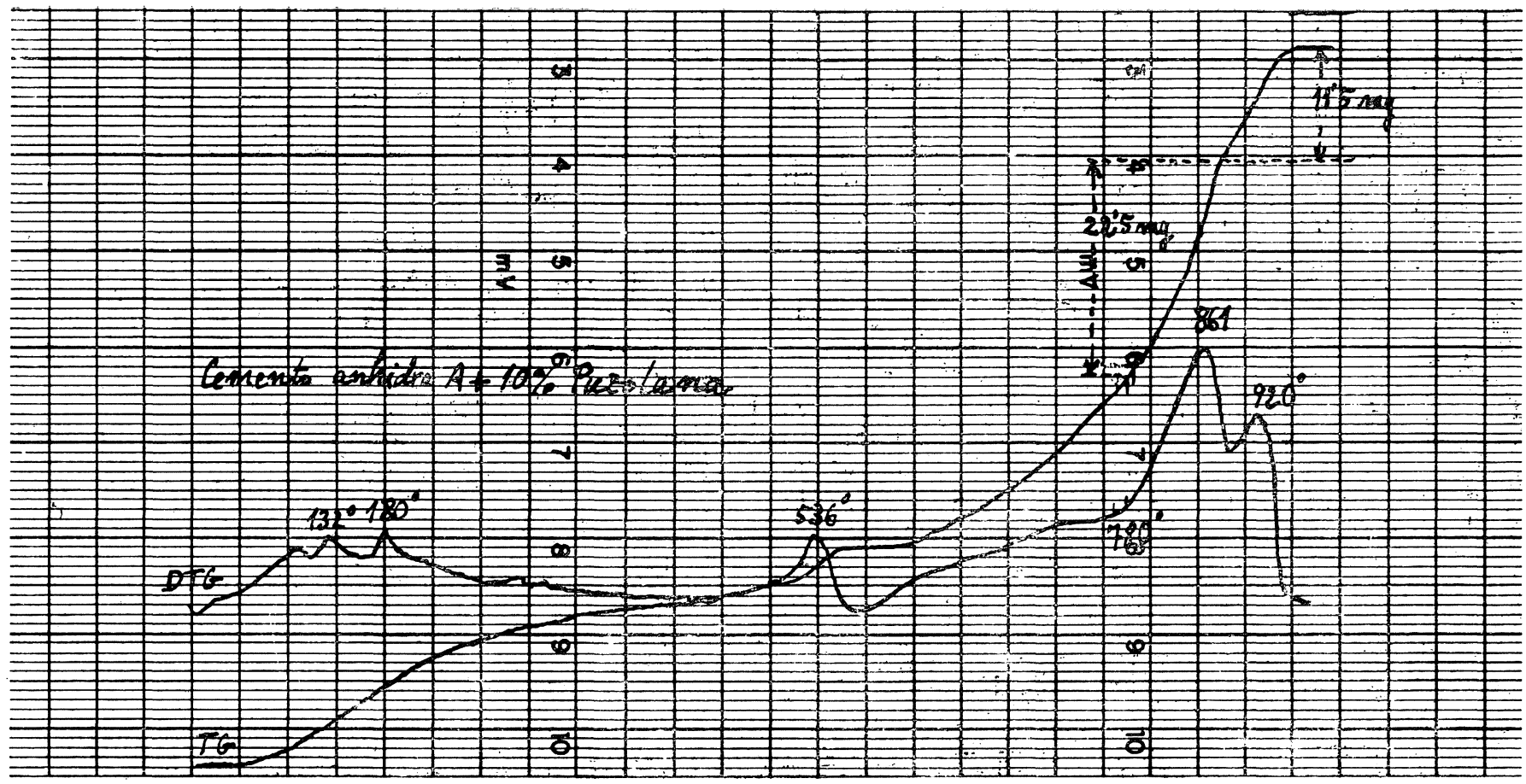

Fig. 6.-Variación del doble pico al realizar el análisis térmico en presencia de $10 \%$ de puzolana íntimamente mezclada con el cemento.

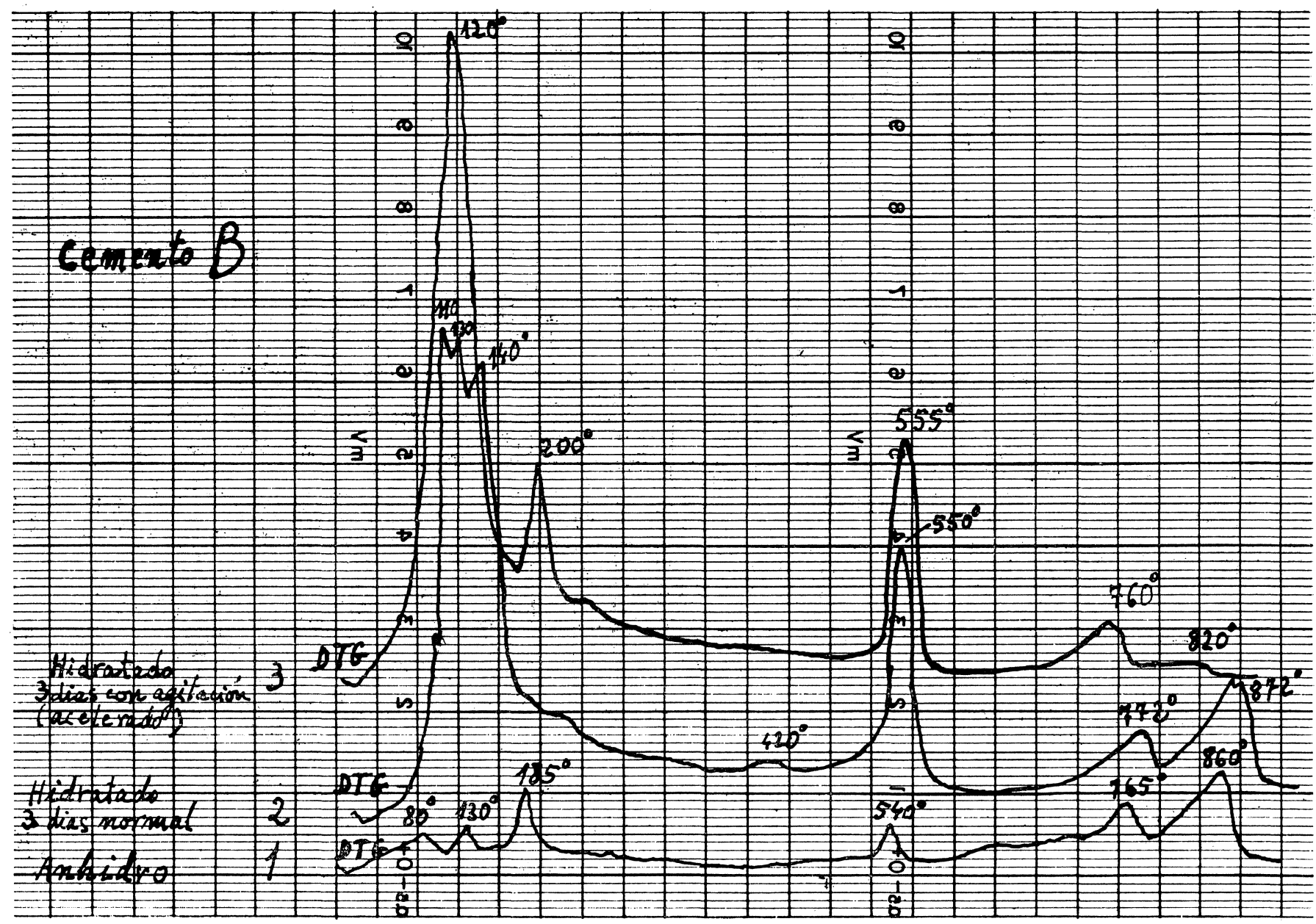

Fig. 7.-Evolución del doble pico de alta temperatura en la hidratación acelerada (agitación durante 3 días con el doble de su peso de agua). 

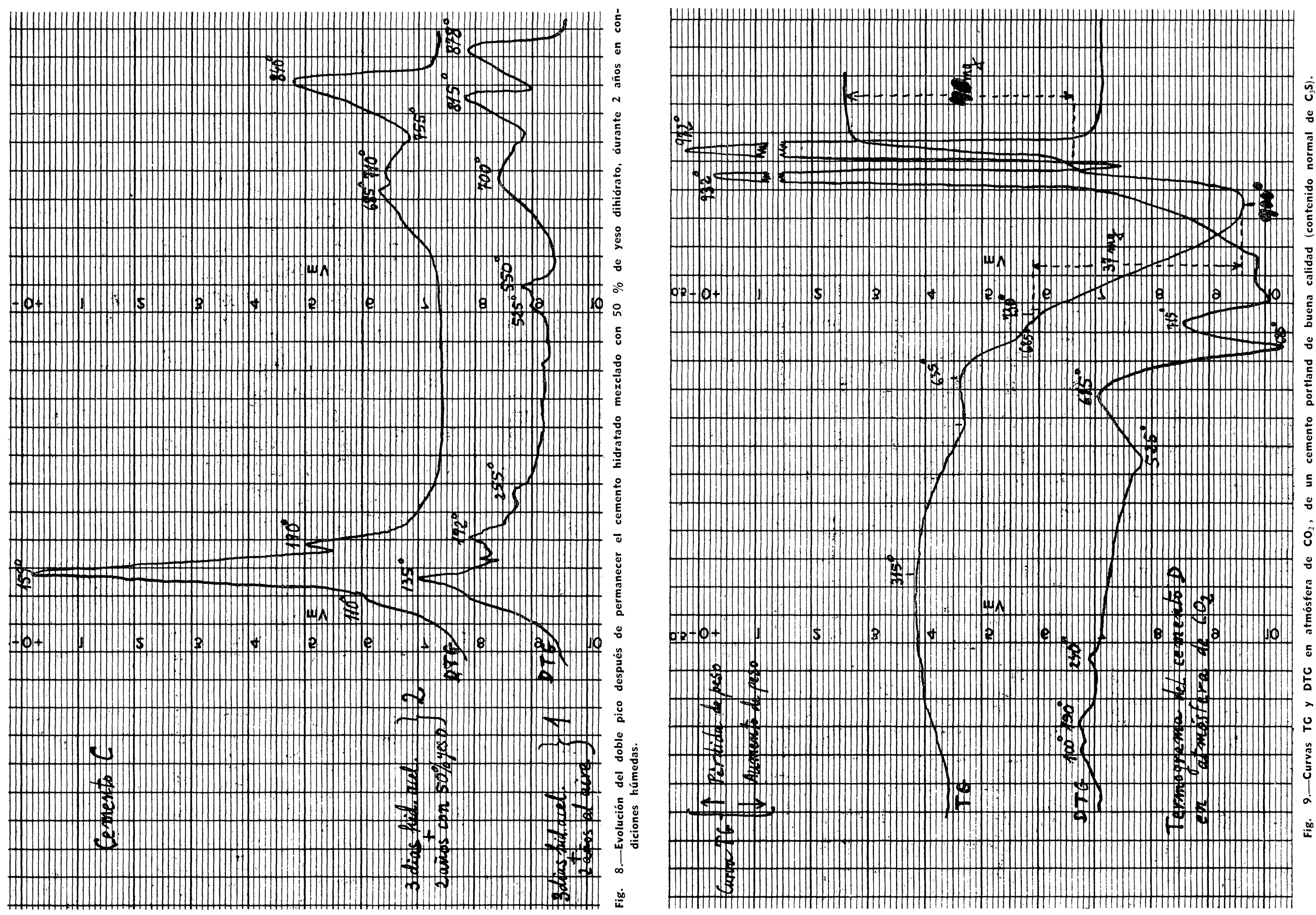


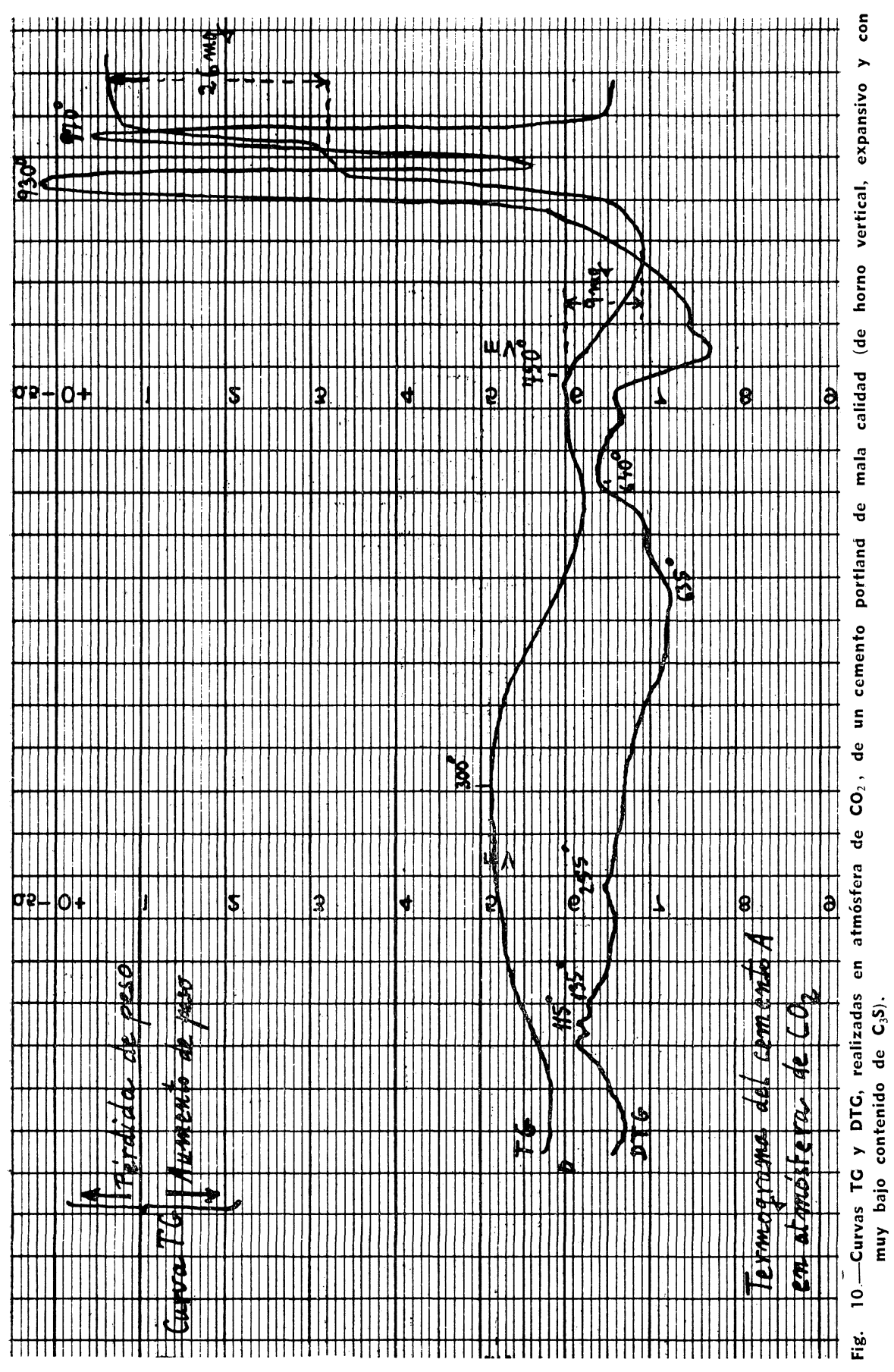

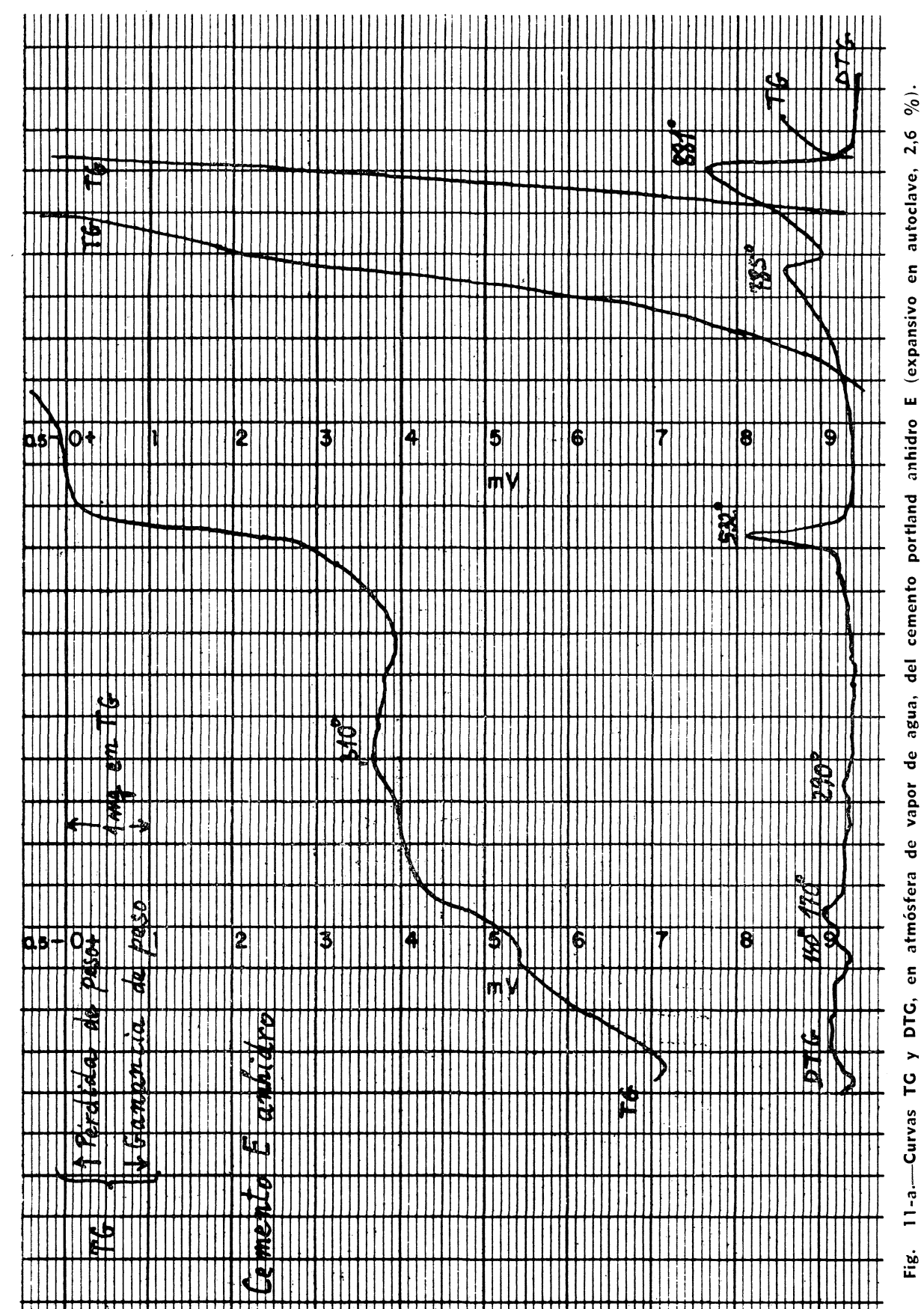

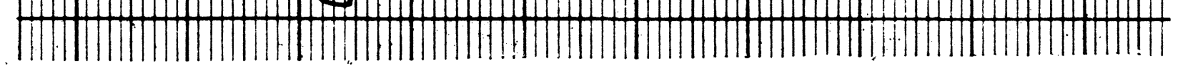




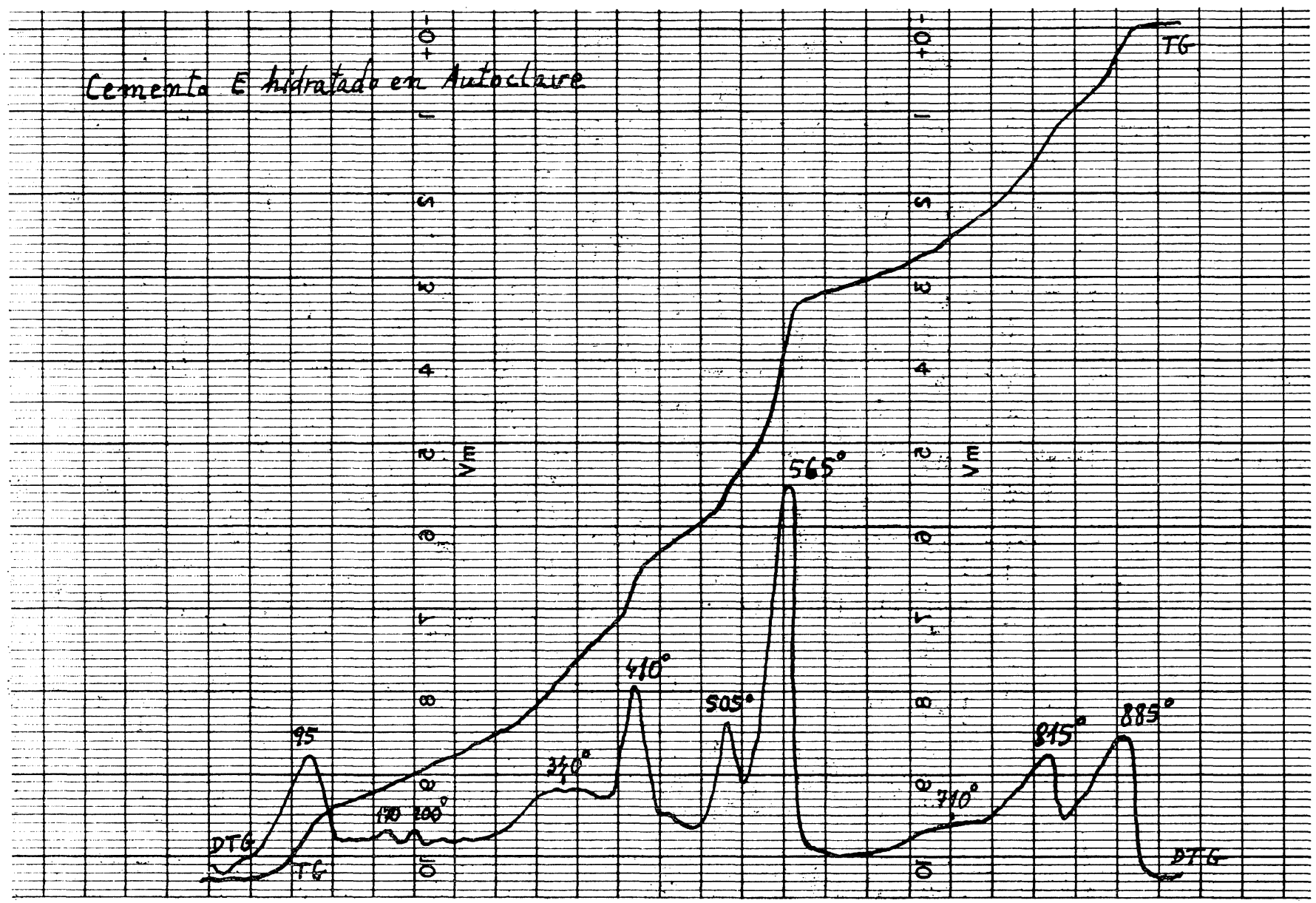

Fig. 11-b.-Curvas TG y DTG, en atmósfera de vapor de agua, de la pasta de cemento portland E hidratada en autoclave (expansión 2,6 \%).

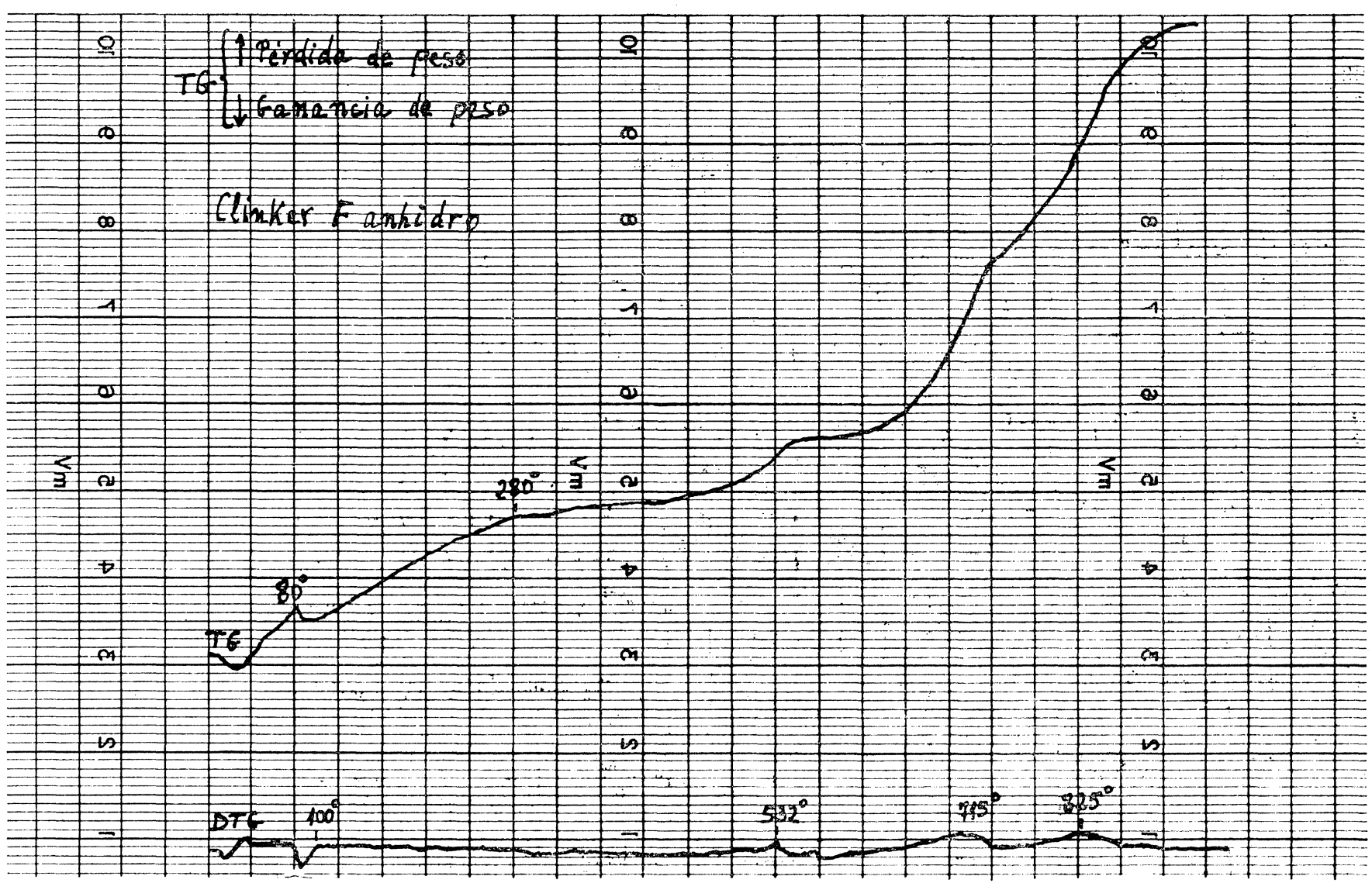

Fig. 12.-Curvas TC y DTC de un clínker que no reacciona con el vapor de agua en el curso del análisis térmico. 


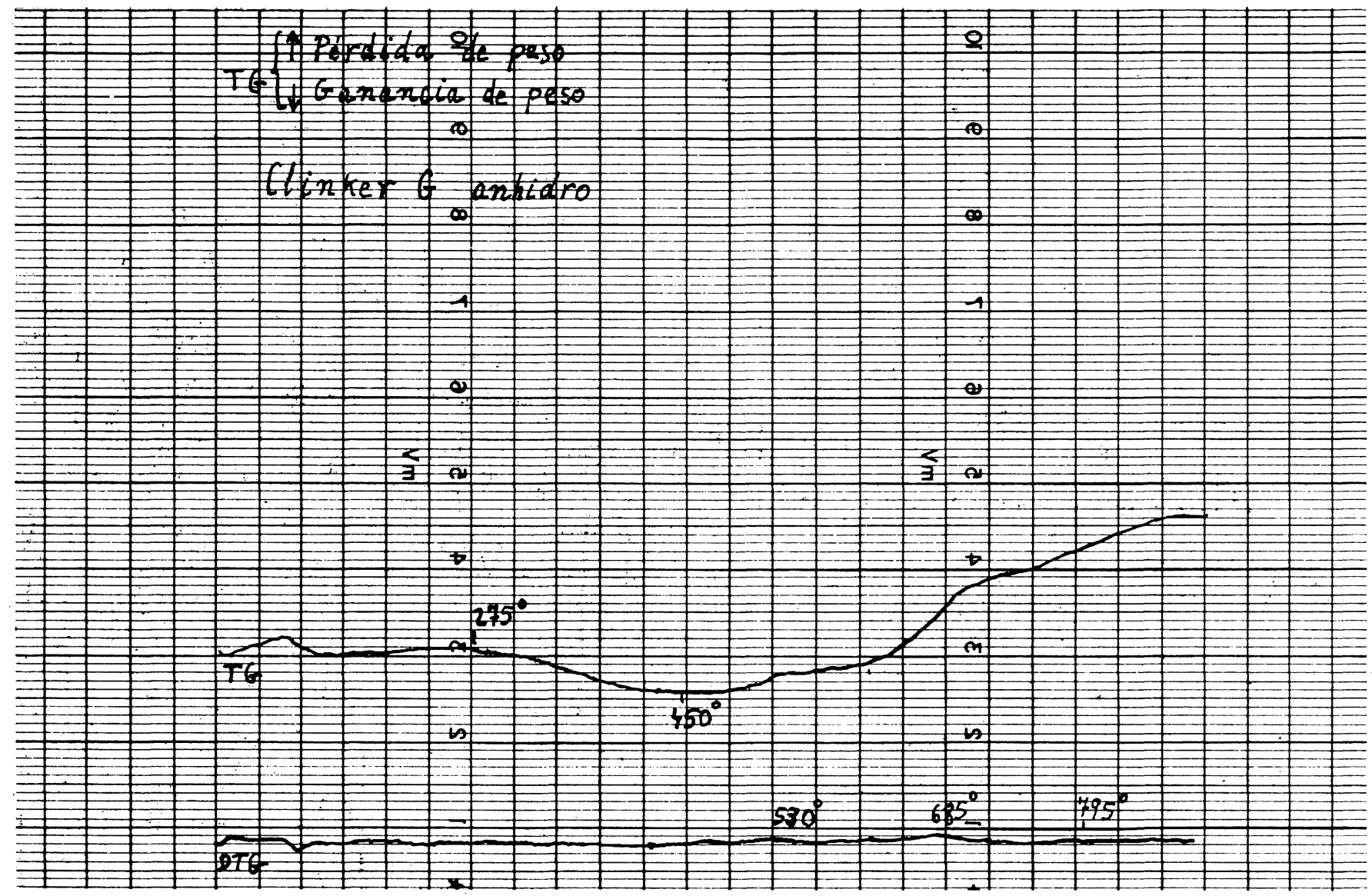

Fig. 13.-Curvas TC y DTC de un clínker que reacciona ligeramente con el vapor de agua en el curso del análisis térmico.

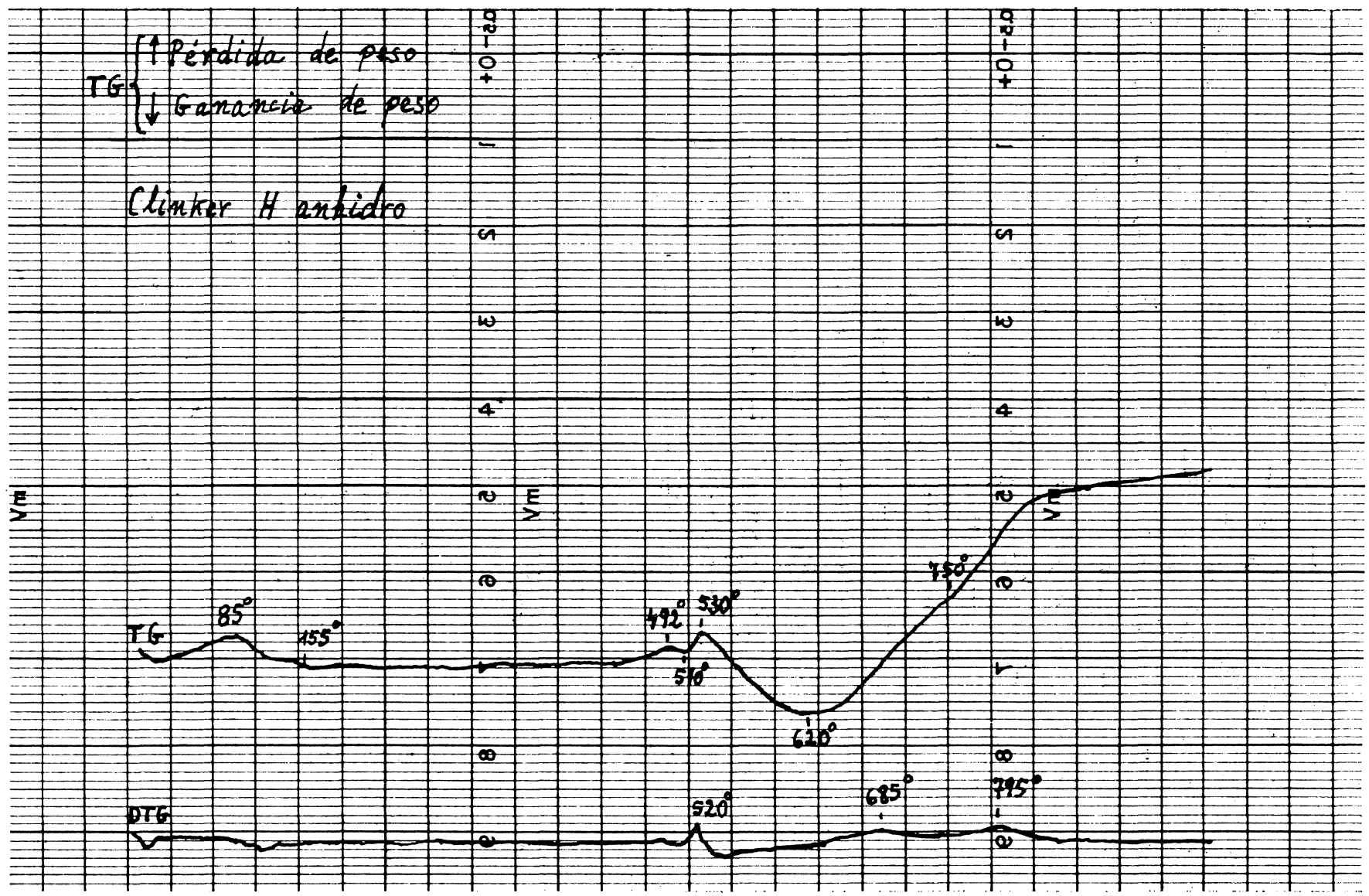

Fig. 14.-Curvas TC y DTC de un clínker que reacciona fuertemente con el vapor de agua en el curso del análisis térmico. 


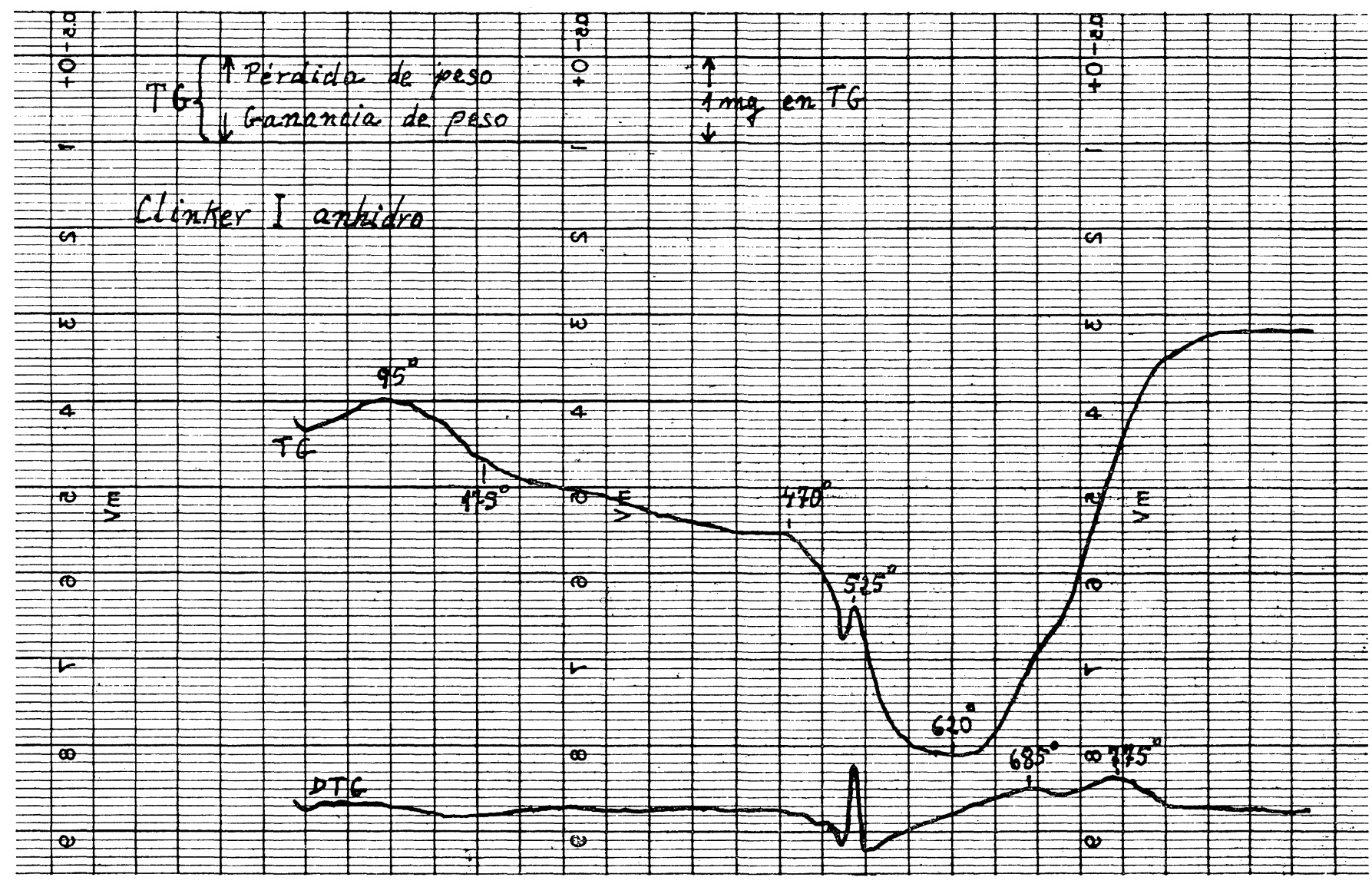

Fig. 15-a.-Curvas TC y DTC del clínker I que reacciona muy fuertemente con el vapor de agua en el curso del análisis térmico.

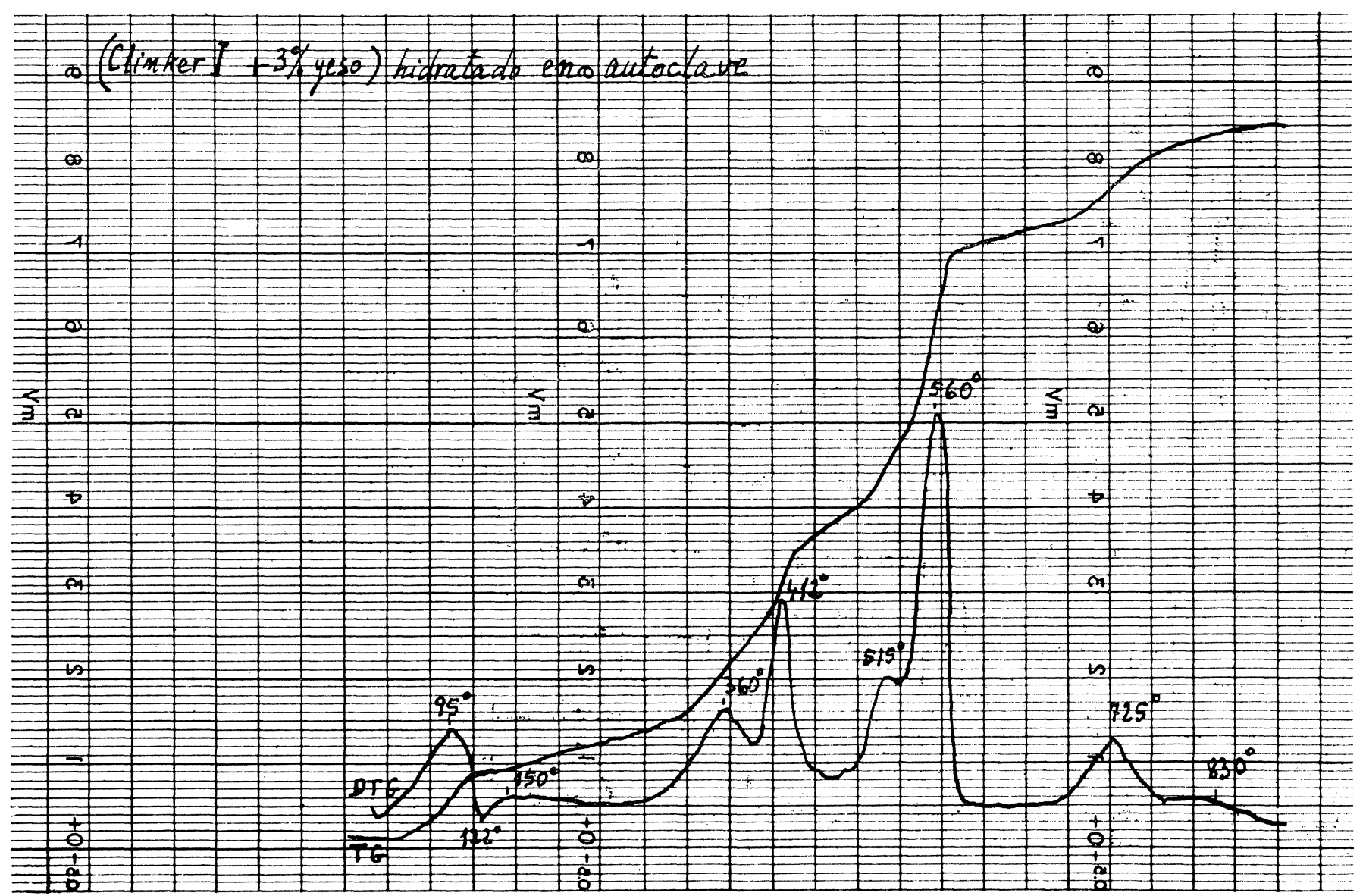

Fig. 15-b.-Curvas TC y DTC de la pasta de cemento, fabricado con el clínker I, hidratada en autoclave (expansión $21 \%$ ). 


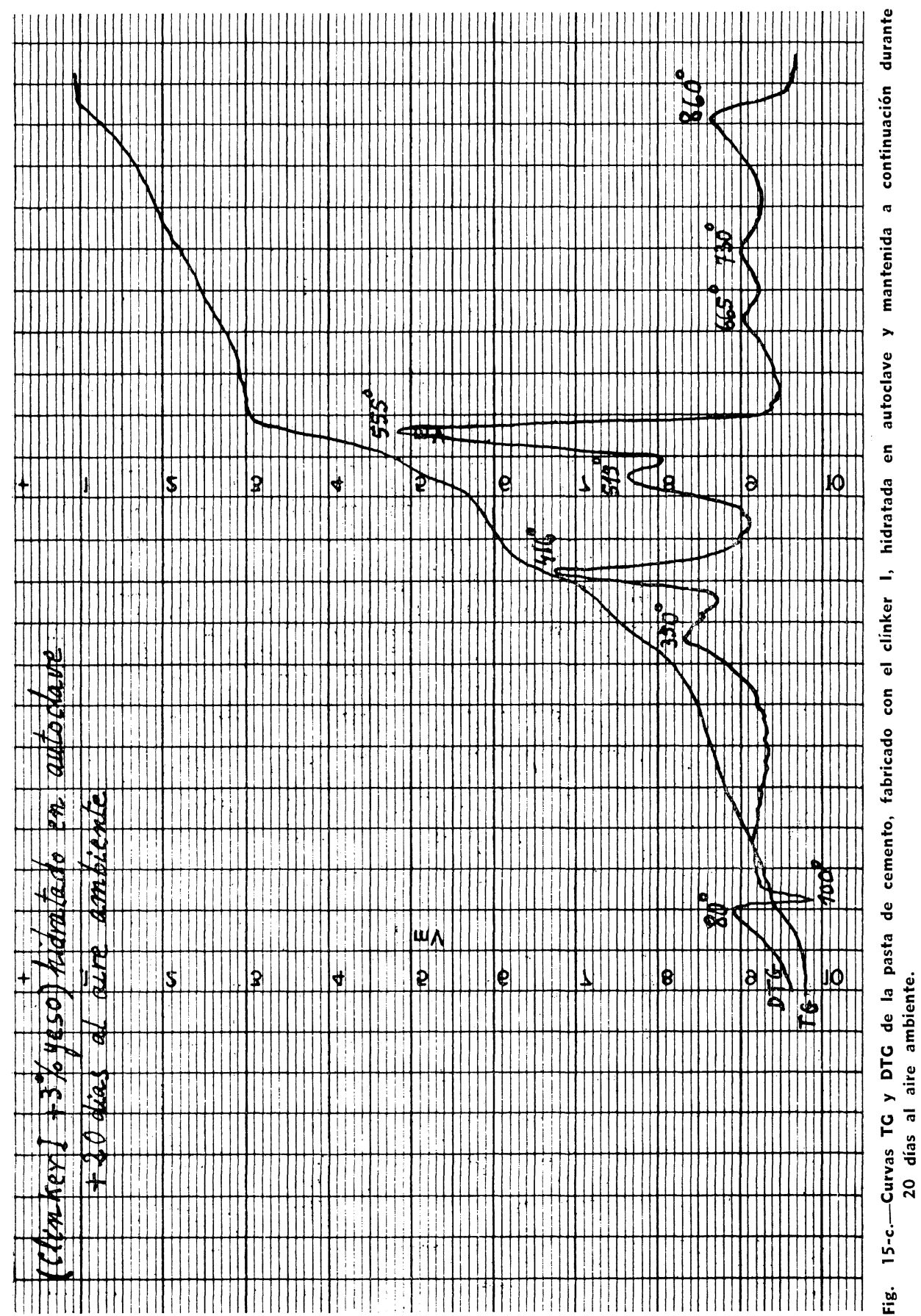

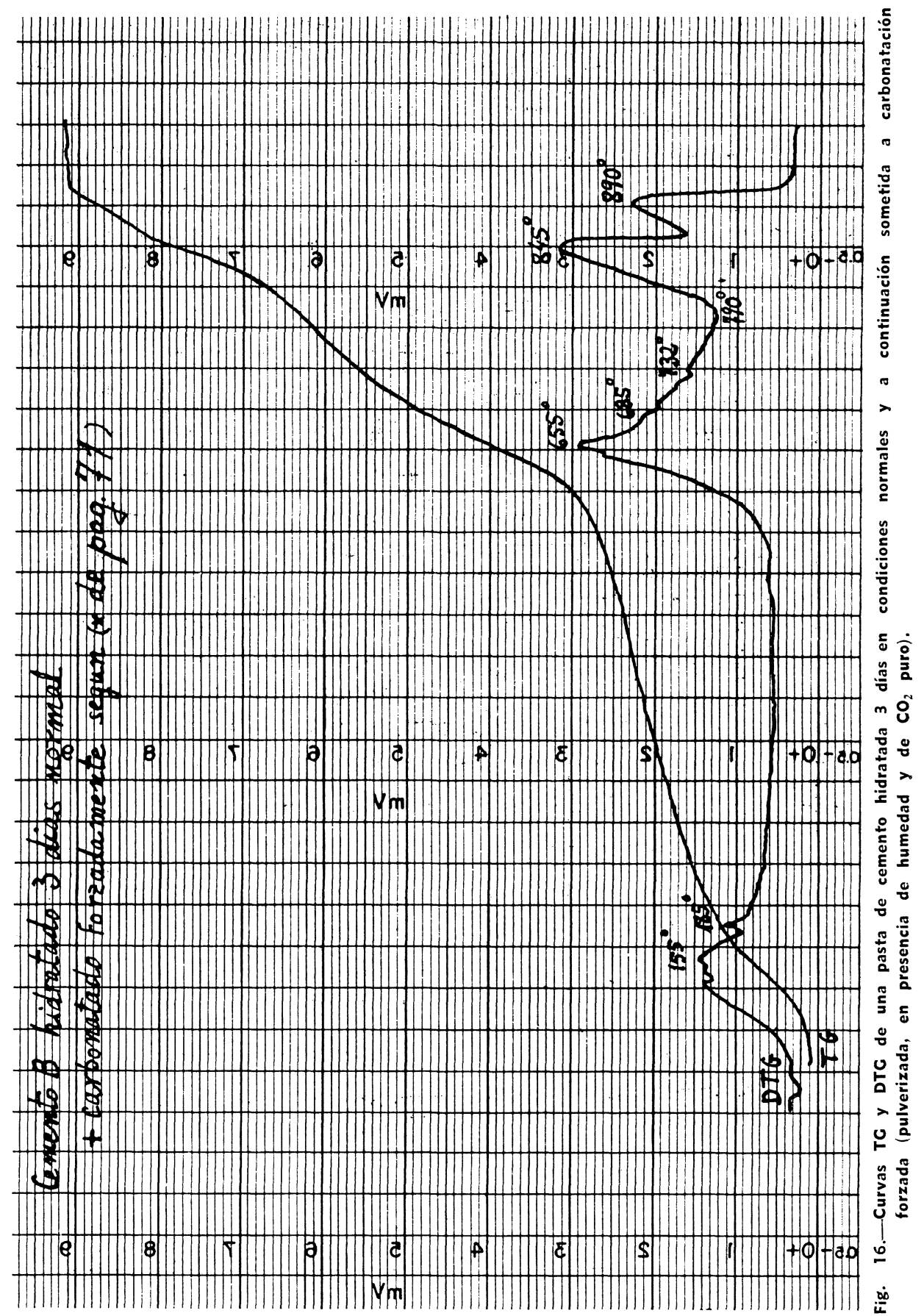

http://materconstrucc.revistas.csic.es 

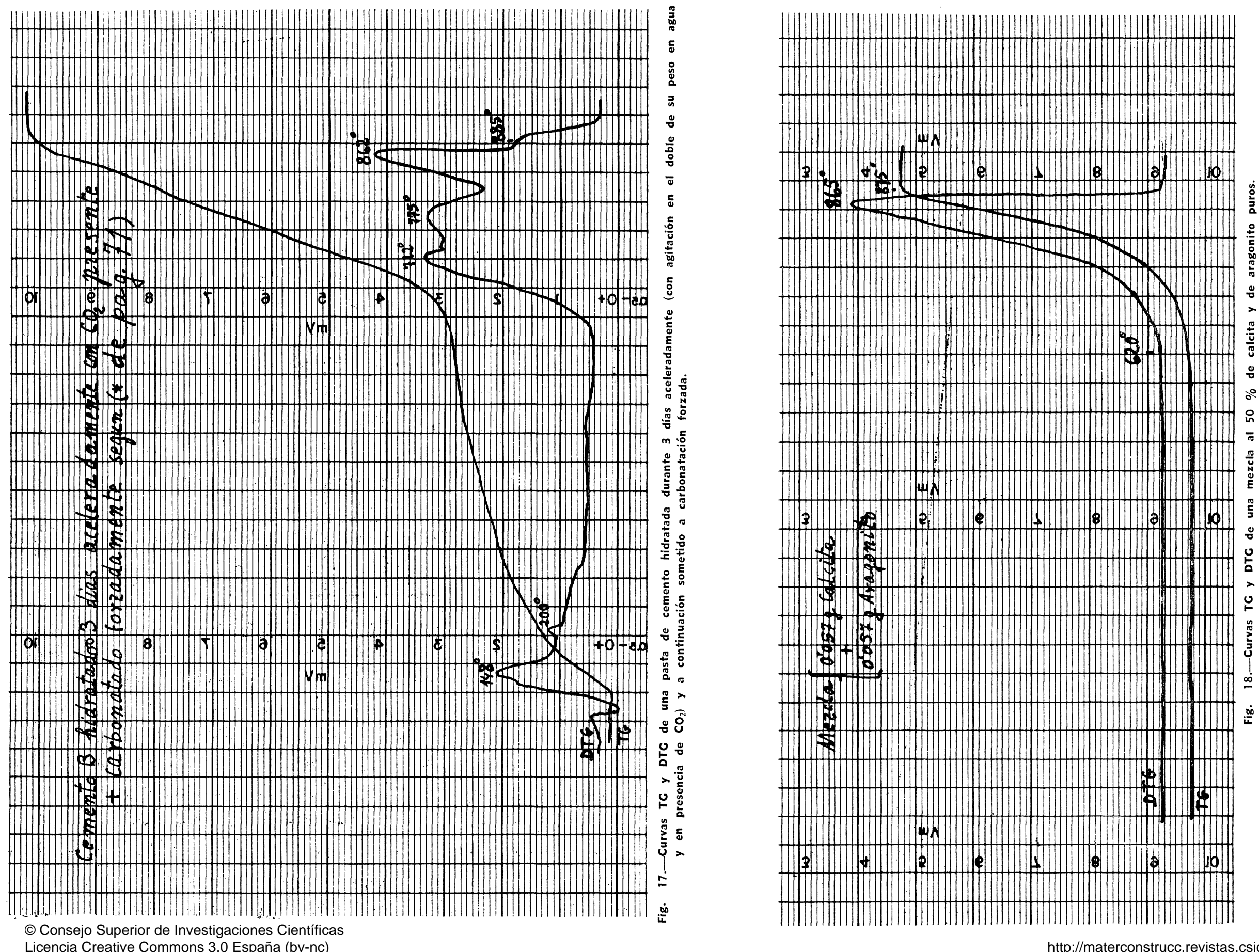


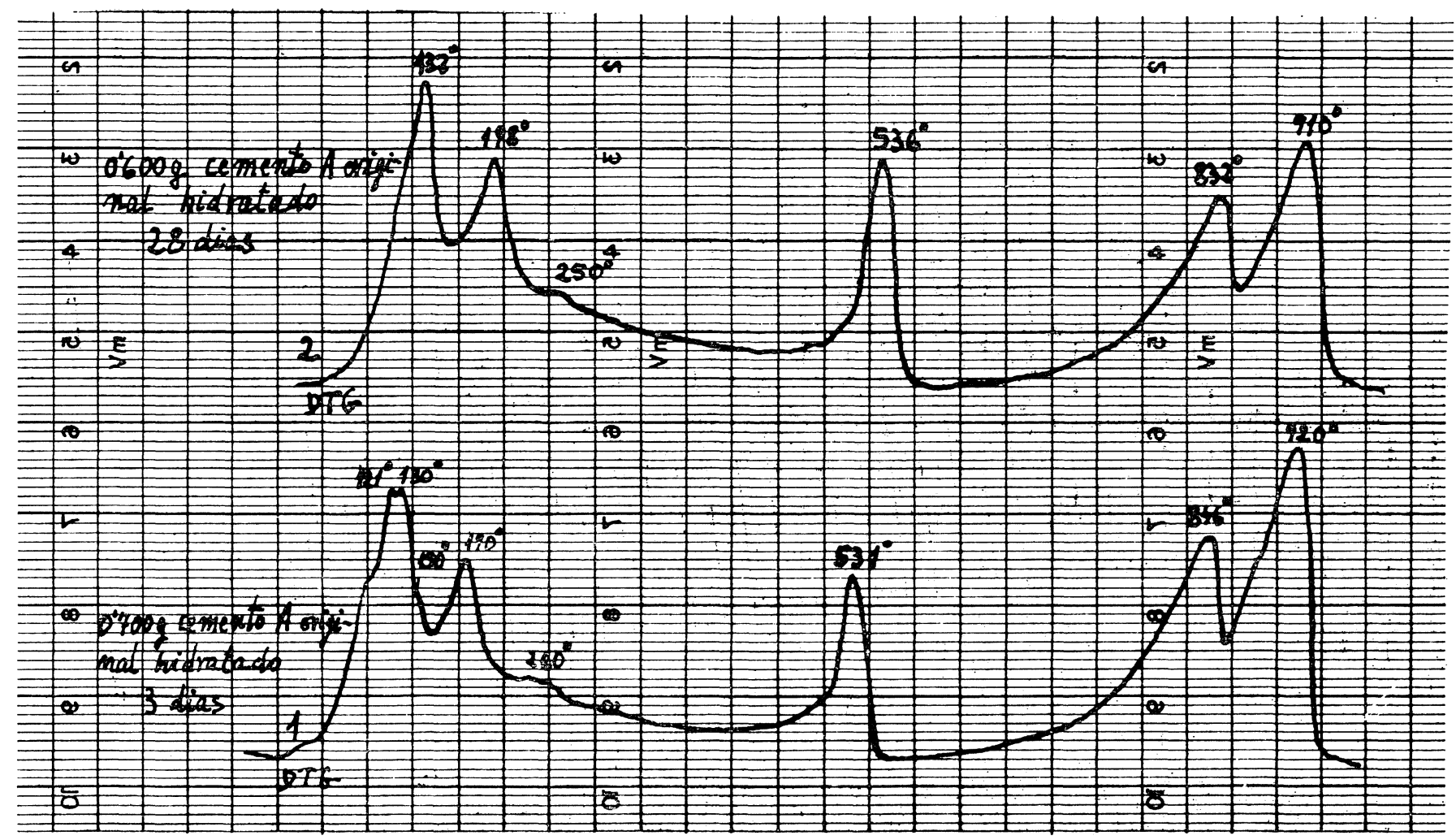

Fig. 19.-Acción de la carbonatación sobre el aluminato tricálcico. Evolución de la curva DTC de la pasta hidratada a 3 días y a 28 días de un cemento portland de horno vertical (cemento $A$ original).

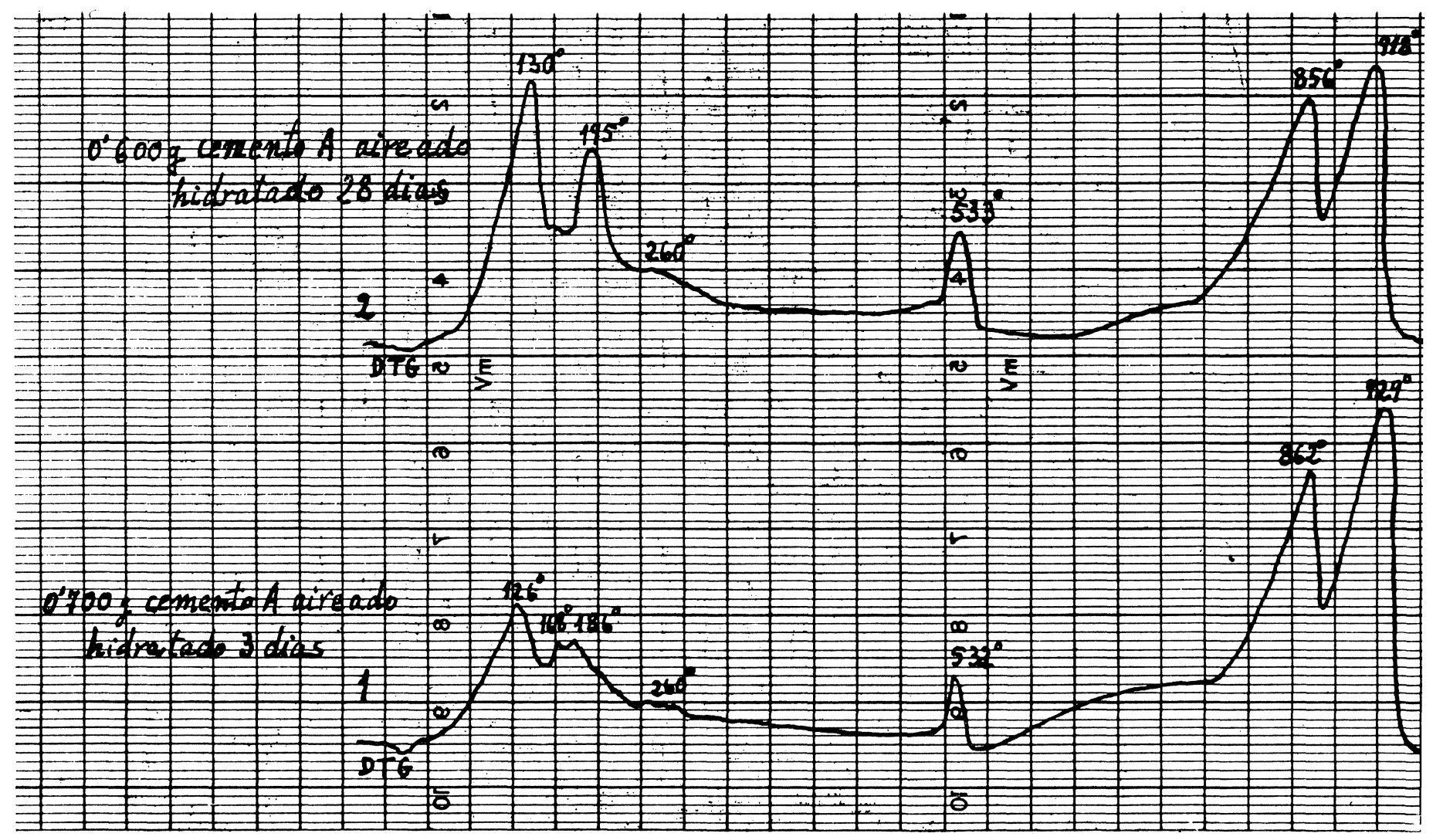

Fig. 20.-Acción de la carbonatación sobre el aluminato tricálcico. Evolución de la curva DTC de la pasta hidratada a 3 días y a 28 días del cemento portland $\mathrm{A}$ sometido a la acción del $\mathrm{CO}_{2}$ húmedo antes de su amasado. 